\title{
NOVEL HYDROGEN SEPARATION DEVICE DEVELOPMENT FOR COAL GASIFICATION SYSTEM APPLICATIONS
}

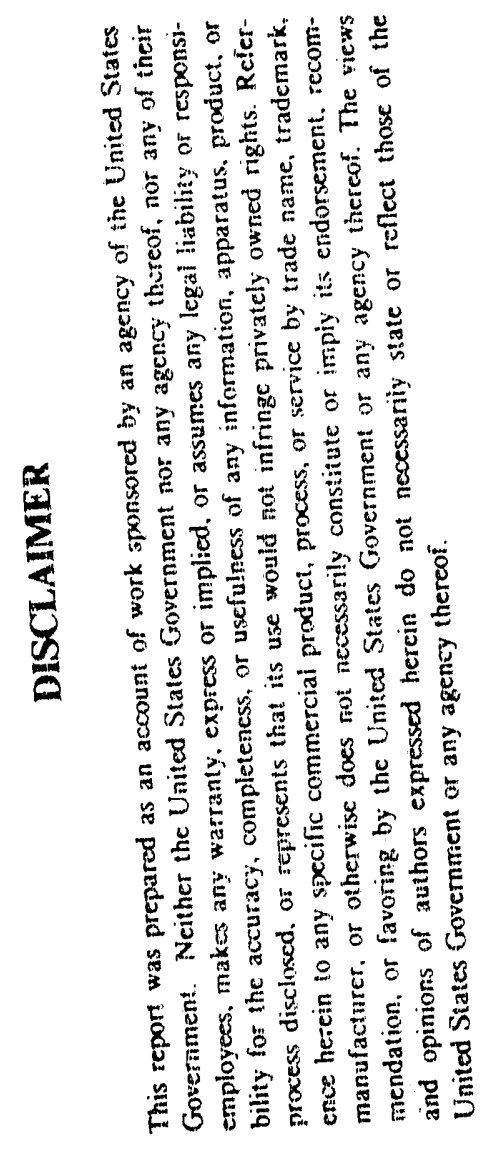

DOE CONTRACT NO. DE-AC21-89MC26040

\section{TOPICAL REPORT TASK 1}

\author{
ing. \\ December, 1991 \\ Prepared For: \\ UNITED STATES DEPARTMENT OF ENERGY \\ Morgantown Energy Technology Center \\ 3610 Collins Ferry Road \\ Morgantown, WiV 26507-0880
}

BY:

ENERGY RESEARCH CENTER

3 Great Pasture Road

Danbury, CT 06813

Ashok Kush, Program Manager

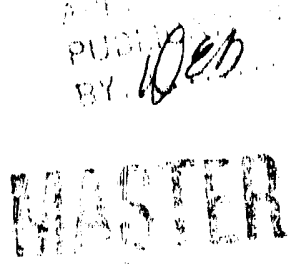

$7 / 28 / 92$

DISTRIBUTION OF THIS DOCUMENT IS UNLIMITEO 
LIST OF CONTRIBUTORS
Mohammad Faroogue
Jennifer Fruchtman
Marge Gaylord
Ashok Kush
Joy MacDonald
Thomas Rostrup-Nielsen 


\section{EXECUTTVE SUMMARY}

This report summarizes all results obtained under Task 1 , Operation and parameter Testing us: ig subscale Cells. Stable EHSD operation was demonstrated with the 4,400 hour life test of an EHSD. It was found that $\mathrm{N}_{2}, \mathrm{CO}_{2}$ and $\mathrm{CH}_{4}$ behave as equivalent inerts; EHSD performance is not affected by the balance of feed gas containing these components. High $\mathrm{H}_{2}$ purity, $>998$, is one of the main features of the EHSD. This product purity level is not sacrificed by increased $\mathrm{H}_{2}$ recovery. $\mathrm{CO}$, however, does adversely affect EHSD performance and therefore feed stream pretreatment is recommended. Concentrations up to $10 \mathrm{ppm} \mathrm{H}_{2} \mathrm{~S}$ and $\mathrm{NH}_{3}$ were added to the feed gas stream to determine their effect on EHSD performance. These impurities did not affect EHSD performance. 


\section{LIST OF FIGURES}

TITLE

PAGE

Figure 1. Schematic of an Electrochemical separation

Device

Figure 2. Schematic of Bulk Separation of Hydrogen

From Coal Gasifier streams

Figure 3. CFC System concept 5

Figure 4. EHSD Performance with Various Diluents 7

Figure 5. EHSD Product Purity 7

Figure 6. Effect of CO Feed content on EHSD 1

Energy Demand

Figure 7. Estimated Performance for EHSD 9

Figure 8. EHSD Performance at Various Pressures 9

Figure 9. Effect of Temperature on EHSD Performance 10

Figure 10. Stable Long-Term EHSR Performance Demonstrated 11

Figure 11. EHSD Perfurmance Using $\mathrm{H}_{2} \mathrm{~S}$ Containing Feed 12

Figure 12. EHSD Performance at Various $\mathrm{H}_{2}$ Flux 13

Figure 13. EHSD Performance with $\mathrm{NH}_{3}$ Containing Feed 14 


\section{LIST OF TABLES}

TITLE

PAGE

Table I. EHSD Design Parameters and Evaluation Ranges

Table 2. Comparison of EHSD Performance Using $\mathrm{H}_{2} \mathrm{~S}$ Containing Feed 


\section{OBJECTIVE}

The objective of this program is to develop an electrochemical hydrogen separation device for cost-effective hydrogen recovery from coal derived gases. The potential applications are high purity hydrogen recovery from oxygen and air blown gasifiers as well as hydrogen-lean streams such as carbonate fuel cell anode exhaust.

In the present program, the effect of design and operating parameters (i.e., pressure, temperature, $\mathrm{H}_{2}$ recovery and electrochemical catalyst loading) on EHSD performance were characterized in single subscale cells $\left(25 \mathrm{~cm}^{2}\right.$ active area) and used to develop a mathematical model. Scale-up, full size (1000 $\mathrm{cm}^{2}$ ) multi-cell stack operation and product purity were also demonstrated.

\section{TECHNICAL BACRGROUND}

The EHSD is an electrochemical hydrogen device based on the uniquely reversible nature of hydrogen oxidation-reduction reactions in electrochemical systems. The design is an offshoot of phosphoric acid fuel cell development. EHSD operating principle and hardware concept are shown in Figure 1. 
Hydrogen from the impure hydrogen stream is oxidized to $\mathrm{H}+$ ions, transported through a cation transport electrolyte membrane under an applied electric field and discharged in a pure hydrogen state on the cathode. (The cation transfer electrolyte membrane also provides a barrier between the feed and product gases.)

Although any proton transfer electrolyte can be used, the phosphoric acid based system offers a unique advantage because of its operating temperature of $-200^{\circ} \mathrm{C}$, which closely matches the gas exiting the water-shift reactor $\left(\sim 250^{\circ} \mathrm{C}\right)$.

Hydrogen-containing streams in coal gasification systems have large carbon monoxide contents. For efficient hydrogen recovery, most of the co must be converted to hydrogen by the low temperature water-shift reaction (Figure 2 ). The residual $c 0$ has a very minor effect on the operation of the EHSD.

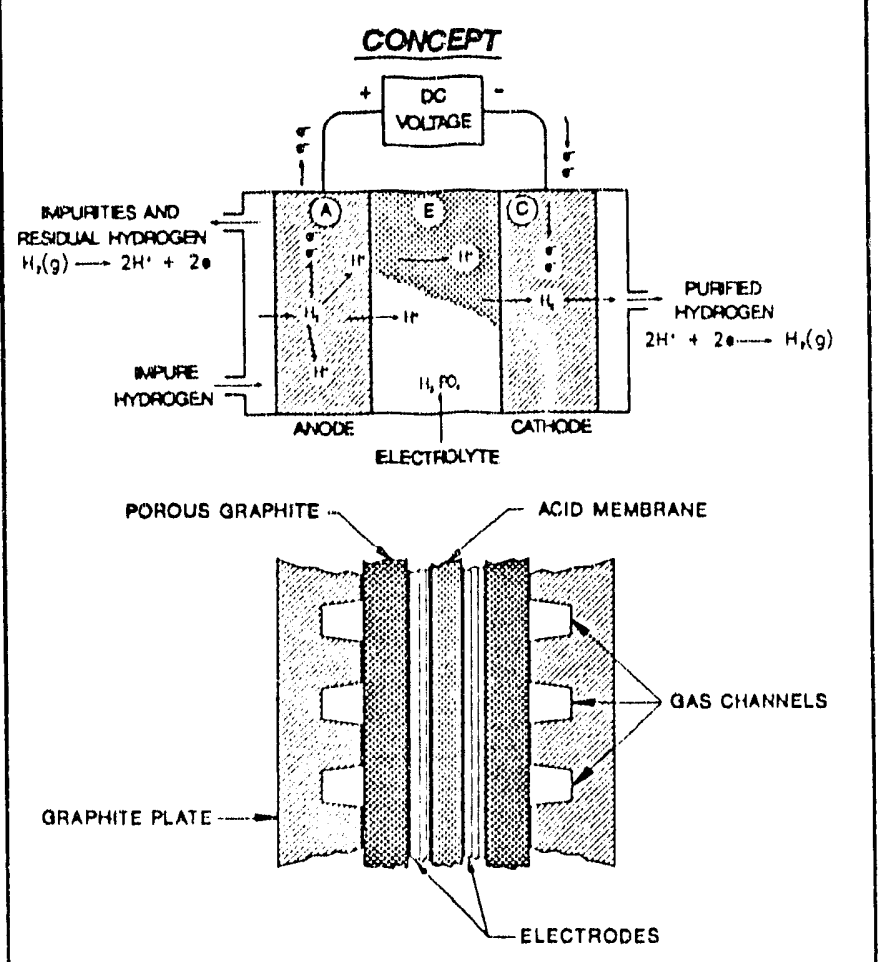

FIGURE 1. SCHEMATIC OF AN ELECTROCHEMICAL SEPARATION DEVICE:

The Highly Reversible Hydrogen oxidation-Reduction Reactions are Utilized for Efficient Hydrogen Separation Employing Cheap Carbon-Based PAFC Technology 
Advanced coal gasification and gas separation technology offer an important pathway to the clean utilization of coal resources in the United states. Hydrogen is used today as a major chemical feed stock and is expected to play an everincreasing role in the future. Thus, the separation technology for recovering hydrogen from coal gasification processes containing 20 to $60 \% \mathrm{H}_{2}$ is greatly needed.

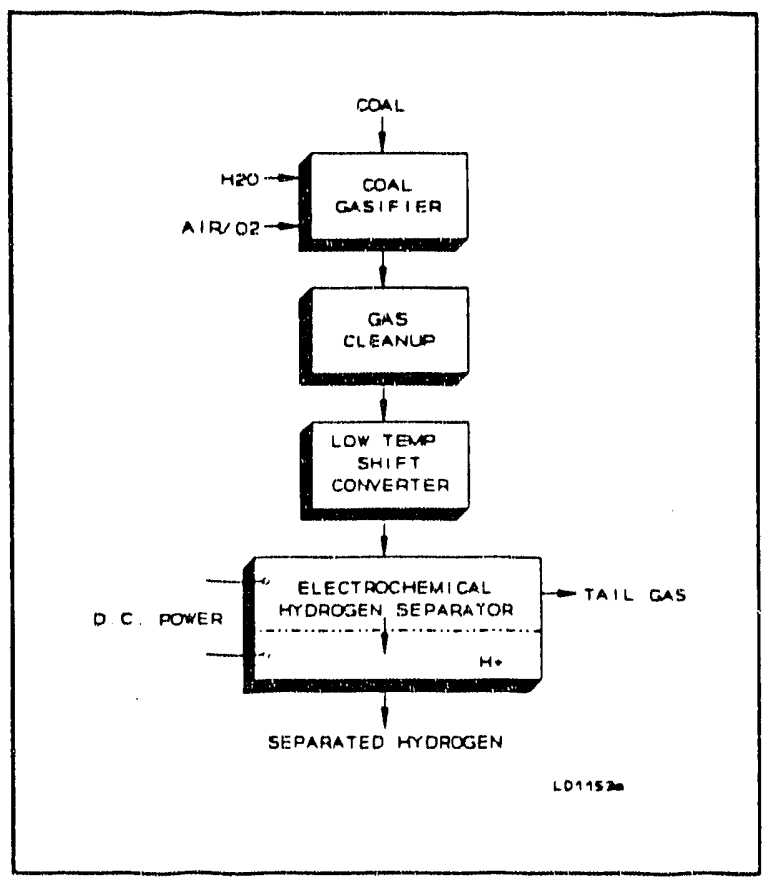

Figure 2. SCHEMATIC OF BULK SEPARATION FROM COAL GASIFIER STREAMS

Commercial and developmental processes known today can be grouped into the following process types:

- Solvent systems based on selective absorption

- Pressure swing absorption in a packed sorbent bed

- Cyrogenic methods

- Semipermeable membranes

These processes operate at moderate to low temperatures and require high pressures. None of these processes are considered very economical for hydrogen-lean streams as encountered in coal gasification (20\% hydrogen in air blown) systems. This presents 
the need for novel concepts to efficiently achieve bulk separation of gases at moderate to high temperatures $\left(100^{\circ}\right.$ to $\left.700^{\circ} \mathrm{C}\right)$.

The electrochemical hydrogen separation device (EHSD), under development at ERC, has several attractive features as follows:

- The operating temperature $\left(-200^{\circ} \mathrm{C}\right)$ is compatible with product gas from low temperature shift reactors.

- Atmospheric as well as elevated pressure can be used, and there is no pressure loss in the system; product $\mathrm{H}_{2}$ is available at the feed stream pressure.

- Recovery of $90 \% \mathrm{H}_{2}$ from feed streams containing less than $10 \%$ hydrogen is feasible.

- The product $\mathrm{H}_{2}$ purity is $>99 \%$ (dry basis) and is virtually independent of $\mathrm{H}_{2}$ concentration in the feed gas.

- Continuous operation. The process requires no equipment regeneration.

- Low energy cost: Depending upon the operating conditions, the energy requirement varies between 2 and $6 \mathrm{kWh} / 1000 \mathrm{SCF}$ of recovered hydrogen. 
Studies under DOE/METC contract $D E-A C 01-87 M C 23274$ have indicated that by using the EHSD, unreacted hydrogen from the carbonate fuel cell anode exhaust can be economically recovered and recycled as shown in Figure 3 . The projected energy efficiency of a carbonate fuel cell power plant containing an EHSD is increased from $54 \%$ to $60 \%$ based on the lower heating value of natural gas.

\section{PROJEC'T DESCRIPTION}

\section{Figure 3. CARBONATE FUEL CELL SYSTEM CONCEPT: $\mathrm{H}_{2}$ Recovery from CFC Anode Exhaust Improves Plant Efficiency}

To accomplish the program objective, the work was broken down into three tasks. In Task 1 , the effects of design and operating parameters on EHSD performance in single subscale $\left(25 \mathrm{~cm}^{2}\right)$ cells were evaluated. The parameters (temperature, pressure, membrane thickness, electrode Pt content, $\mathrm{H}_{2}$ feed content, feed gas impurities, current density, and hydrogen recovery) and their ranges are presented in rable 1. A mathematical performance model was developed for design calculations. Task 2 involved the demonstration of scale-up, multi-cell operation and product quality. The cost of the EHSD system will be compared with a competing separation technology in 
Table I. EHSD DESIGN PARAMETERS AND EVALUATION RANGES

\begin{tabular}{|c|c|c|}
\hline PARAMETER & RANGE & UNIT \\
\hline TEMPERATURE & $190 \quad 200 \quad 220$ & ${ }^{\circ} \mathrm{C}$ \\
\hline PRESSURE & 1 THROUGH 10 & Atm \\
\hline MEMBRANE THICKNESS & 0.2 THROUGH 0.4 & $\mathrm{~mm}$ \\
\hline ANODE PE CONTENT & 0.2 THROUGH 0.55 & $\mathrm{mg} \mathrm{Pt} / \mathrm{cm}^{2}$ \\
\hline CATHODE PE CONTENT & 0.2 THROUGH 0.55 & $\mathrm{mg} \mathrm{Pt} / \mathrm{cm}^{2}$ \\
\hline $\mathrm{H}_{2}$ FEED CONCENTRATION & $5 \quad 10 \quad 30 \quad 60$ & mole $\frac{\%}{6}$ \\
\hline $\begin{array}{c}\text { FEED GAS IMPURITIES, } \\
\left(\mathrm{H}_{2} \mathrm{~S}, \mathrm{NH}_{3}\right)\end{array}$ & 3 Tо 10 & $\mathrm{ppm}$ \\
\hline CURRENT DENSITY & UP TO 400 & $\mathrm{~mA} / \mathrm{cm}^{2}$ \\
\hline HYDROGEN RECOVERY & UP TO 90 & $\%$ \\
\hline
\end{tabular}

Task 3 .

\section{RESULTS}

It was previously established that EHSD performance is not affected by the balance of the feed gas, whether $\mathrm{CH}_{4}, \mathrm{~N}_{2}$, or $\mathrm{CO}_{2}$ (Figure 4). This is an important feature of the EHSD because, unlike other separation devices, EHSD product hydrogen purity and recovery are independent of the relative concentrations of other major components in the feed gas. The EHSD can be used with air or oxygen blown gasifier exhaust (with a typical dry composition range of 30-60\% $\left.\mathrm{H}_{2}, 1-45 \% \mathrm{~N}_{2}, 24-35 \% \mathrm{CO}_{2}, 1-4 \% \mathrm{CH}_{4}\right)$, as well as methane producing gasifiers (with an approximate dry composition of $26 \% \mathrm{H}_{2}$, $\left.18 \% \mathrm{~N}_{2}, 29 \% \mathrm{CO}_{2}, 27 \% \mathrm{CH}_{4}\right)$. It was also verified that the EHSD is capable of recovering $90 \% \mathrm{H}_{2}$ with a purity of greater than $99 \%$ 
from low hydrogen concentration streams such as carbonate fuel. cell anode exhaust. This product purity increases with rate of recovery which signifies that high product hydrogen purity is not sacrificed by high hydrogen recovery (Figure 5).

\section{Several EHSD design} parameters were investigated. It was determined that lowering the electrode platinum content

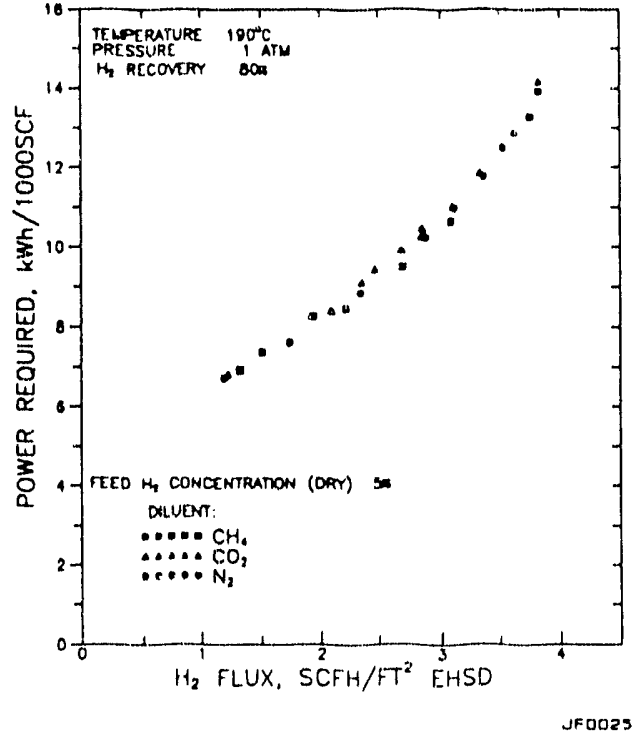

Figure 4. EHSD PERFORMANCE WITH VARIOUS DILUENTS: $80 \%$ Recovery is Feasible with Dilute $\mathrm{H}_{2}$ Containing streams: $\mathrm{CH}_{4}, \mathrm{CO}_{2}$, and $\mathrm{N}_{2}$ Behave as Equivalent Inerts.

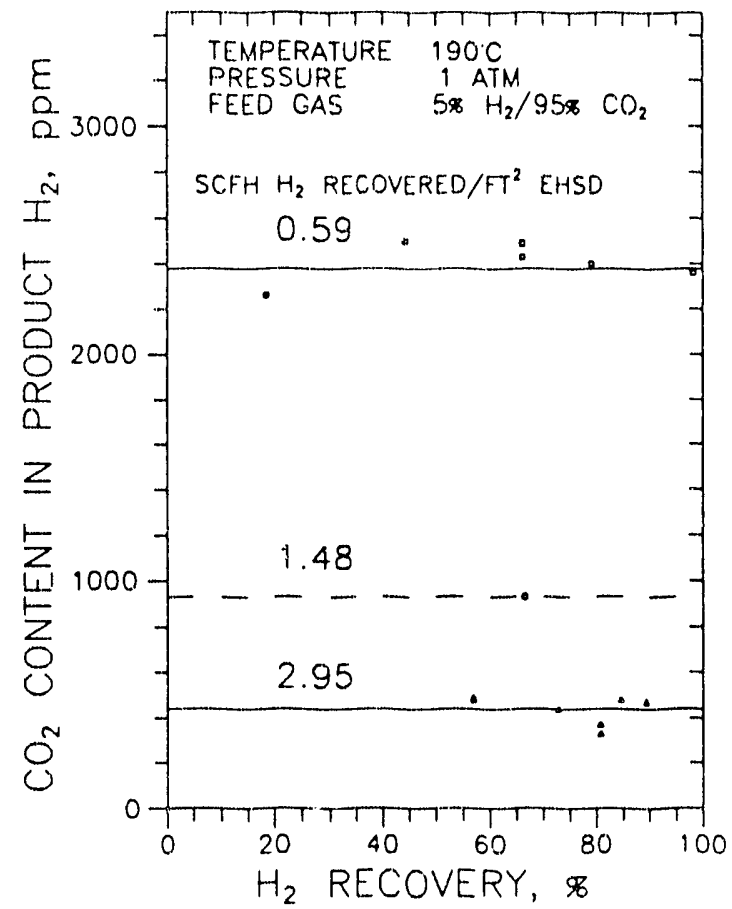

Figure 5a. PRODUCT PURITY vs. $\mathrm{H}_{2}$ RECOVERY

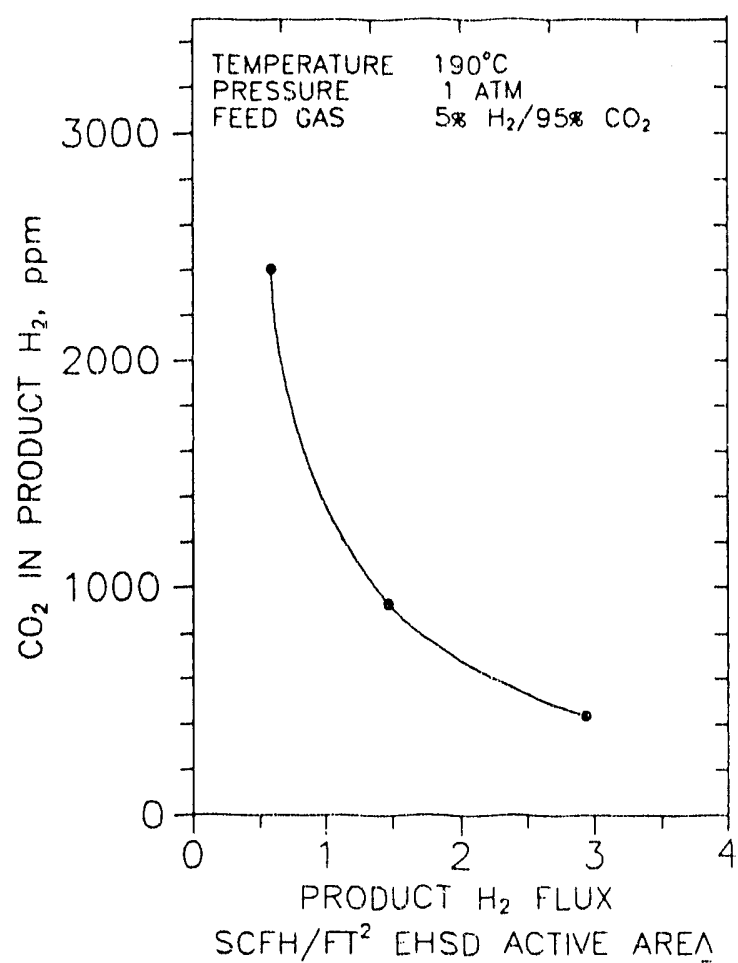

Figure 5b. PRODUCT PURITY vS. FLUX 
from 0.5 to $0.26 \mathrm{mg} \mathrm{pt} / \mathrm{cm}^{2}$ did not affect EHSD energy requirement. This results in a reduction of EHSD capital cost. The EHSD membrane produces a resistive power demand which increases proportionally with membrane thickness. It was established that the membrane remains effective at a thickness in the range of $0.2-0.3 \mathrm{mn}$ and therefore

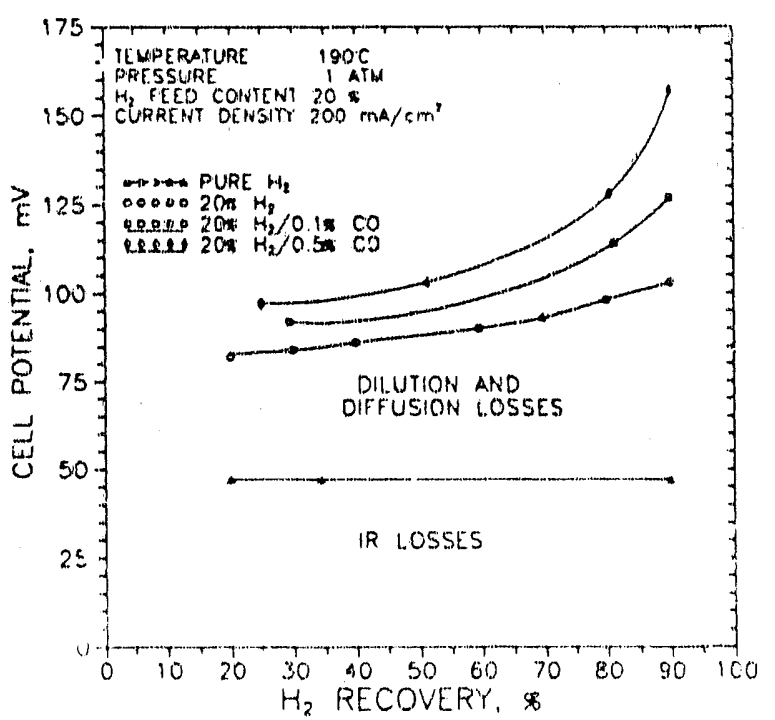

Figure 6, EFFECT OF CO FEED CONTENT ON EHSD POWER DEMAND

Co Feed rontent and $\mathrm{B}_{2}$ Recovery Increase Power Demand

reduces the resistive energy demand.

EHSD performance is affected by the presence of co in the feed stream and is dependant on $\mathrm{H}_{2}$ and $\mathrm{CO}$ content as well as the $\mathrm{H}_{2}$ recovery (Figure 6). This effect is greater with low $\mathrm{H}_{2}$ concentrations which indicates that pretreatment to reduce co content in the feed gas is beneficial to the EHSD system.

A mathematical model was developed to predict EHSD power consumption for gases containing as low as $5 \%$ hydrogen. This model fits well with experimental data as shown in Figure 7 . A well-developed model is an essential tool for plant design calculations and economic analysis. 


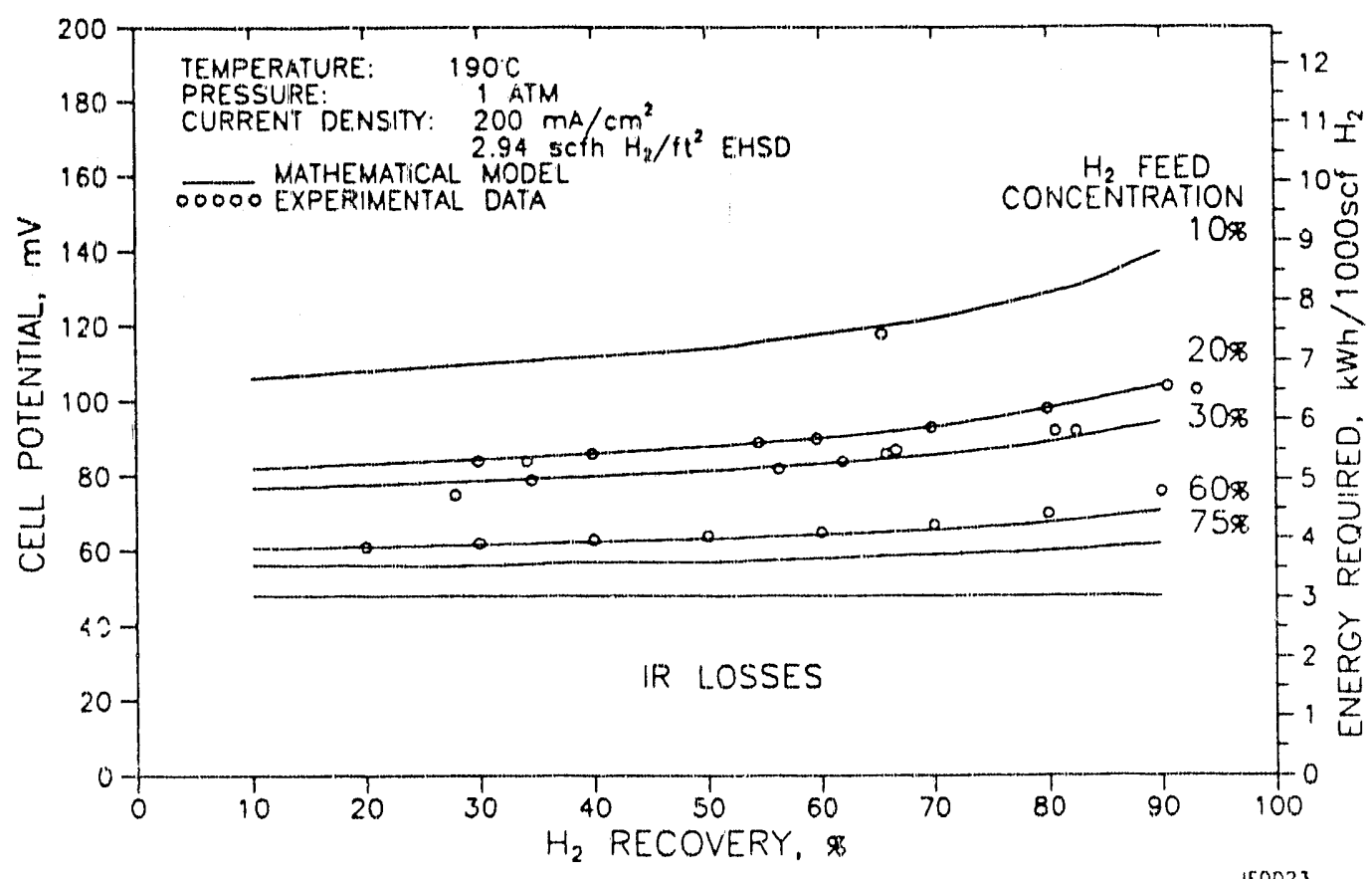

Figure 7. ESTIMATED PERFORMANCE FOR EHSD

The Mathematical Model is in Good Agreement with EHSD Experimental Results in a Range of $\mathrm{H}_{2}$ Concentrations

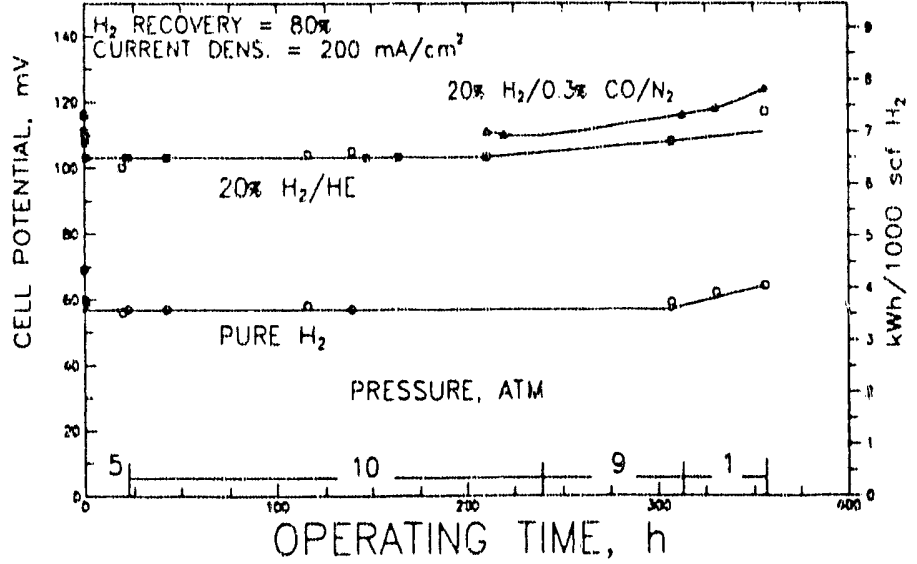

Figure 8. EHSD PERFORMANCE AT

VARIOUS PRESSURES

EHSD Performance is Not Affected by pressure
EHSD performance at various pressures was evaluated using several feed streams. Increasing operating pressure above atmospheric may reduce the electrical resistance of the EHSD and therefore show an 


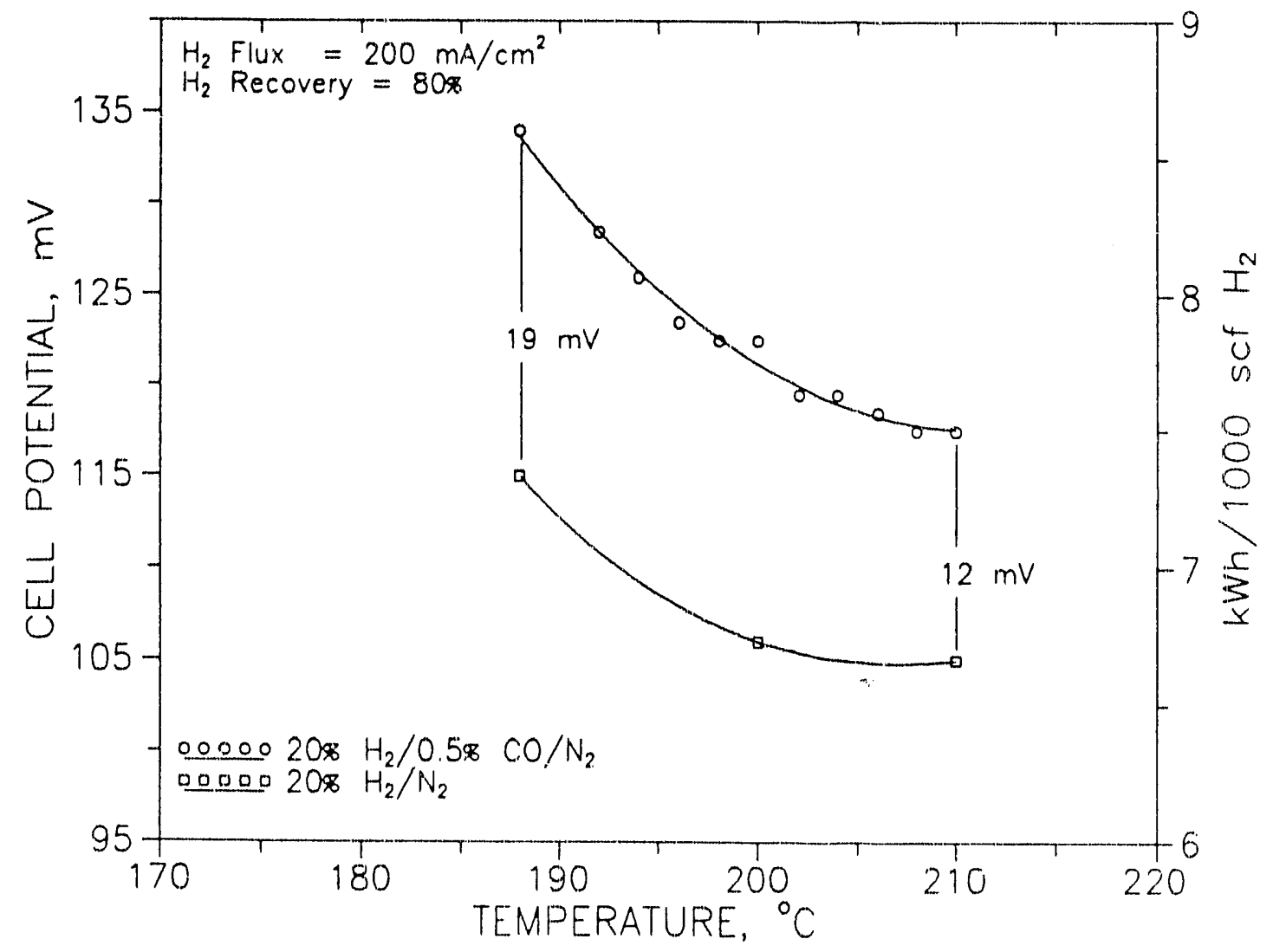

Figure 9. EFFECT OF TEMPERATURE ON EHSD

PERFORMANCE

Increasing the operating Temperature Decreases EHSD Power Requirement

initial decrease in required energy (Figure 8). Varying the pressure above one atmosphere does not affect the EHSD energy demand.

The effect of temperature on EHSD energy consumption was established. As expected, the power demand decreases as operating temperature increases (Figure 9). This is an important attribute of the EHSD system because it operates at temperatures 
closely matching that of the gas exiting the water gas shift reactor and also adds versatility to the EHSD operating system.

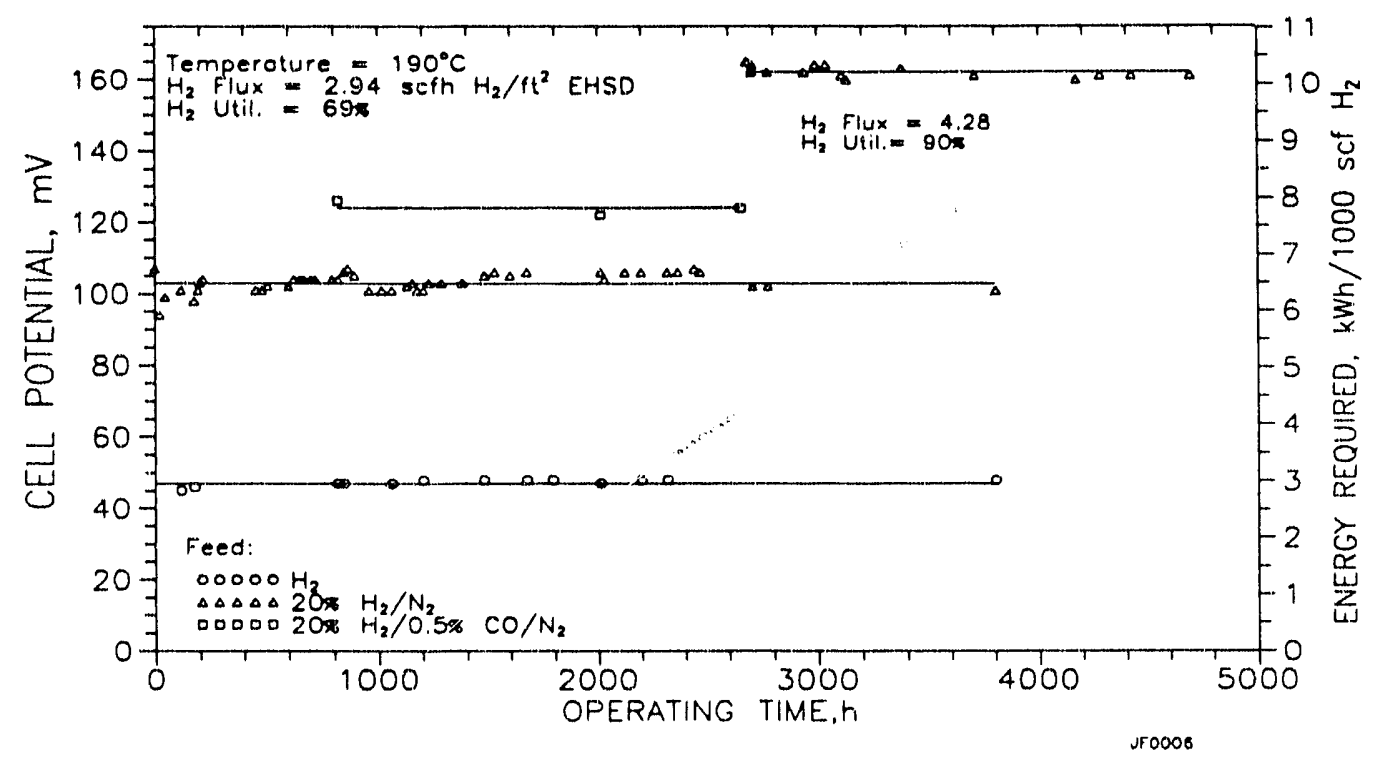

Figure 10. STABLE LONG-TERM PERFORMANCE DEMONSTRATED

EHSD Performance Stability Demonstrated at Increased $\mathrm{H}_{2}$ Filux and Recovery

Long-term stable EHSD operation has been demonstrated. A subscale EHSD cell has operated for over 4,400 hours on a variety of feeds and at stringent operating conditions (Figure 10). The energy requirement remained stable throughout its operating life.

Studies were also conducted using feed streams containing trace quantities of $\mathrm{NH}_{3}$ and $\mathrm{H}_{2} \mathrm{~S}$. Research conducted on PAFC operaiing conditions has established that the presence of even small quantities of $\mathrm{H}_{2} \mathrm{~S}$ or $\mathrm{NH}_{3}$ may adversely affect fuel cell 
performance. As trace quantities of these components may be present in coal gasifier product streams, a study was undertaken to determine what effect they may have on EHSD performance.

Table 2. Comparison of EHSD The sulfur tolerance of the Performance Using $\mathrm{H}_{2} \mathbf{S}$ EHSD was investigated with subscale $\left(.25 \mathrm{~cm}^{2}\right)$ cell tests. A variety of feed compositions containing up to $10 \mathrm{ppm} \mathrm{H}_{2} \mathrm{~S}$ were studied and the results indicate Containing Feed.

that EHSD performance is not

\begin{tabular}{||l|c|c|}
\hline $\begin{array}{l}\text { Feed } \\
\text { Composition }\end{array}$ & $\begin{array}{c}10 \mathrm{ppm} \\
\mathrm{H}_{2} \mathrm{~S} \\
\mathrm{Bal}\end{array}$ & $\begin{array}{c}\text { Neat } \\
\mathrm{H}_{2}\end{array}$ \\
\hline $\begin{array}{l}\text { Energy } \\
\text { Required, } \mathrm{mV}\end{array}$ & 66 & 67 \\
\hline
\end{tabular}

affected by low levels of $\mathrm{H}_{2} \mathrm{~S}$. The EHSD energy requirement using neat hydrogen and a $10 \mathrm{ppm} \mathrm{H}_{2}$ S/hydrogen feed are compared in Table 2. There is no change in EHSD performance due to the adaition of the $\mathrm{H}_{2} \mathrm{~S}$. Short term stability tests show that the energy requirement of a dilute $\mathrm{H}_{2}$ stream containing 3.5 ppm $\mathrm{H}_{2} \mathrm{~S}$ is comparative to the EHSD energy requirement when using a dilute $\mathrm{H}_{2} \mathrm{~S}$-free feed streams as shown in Figure 11.

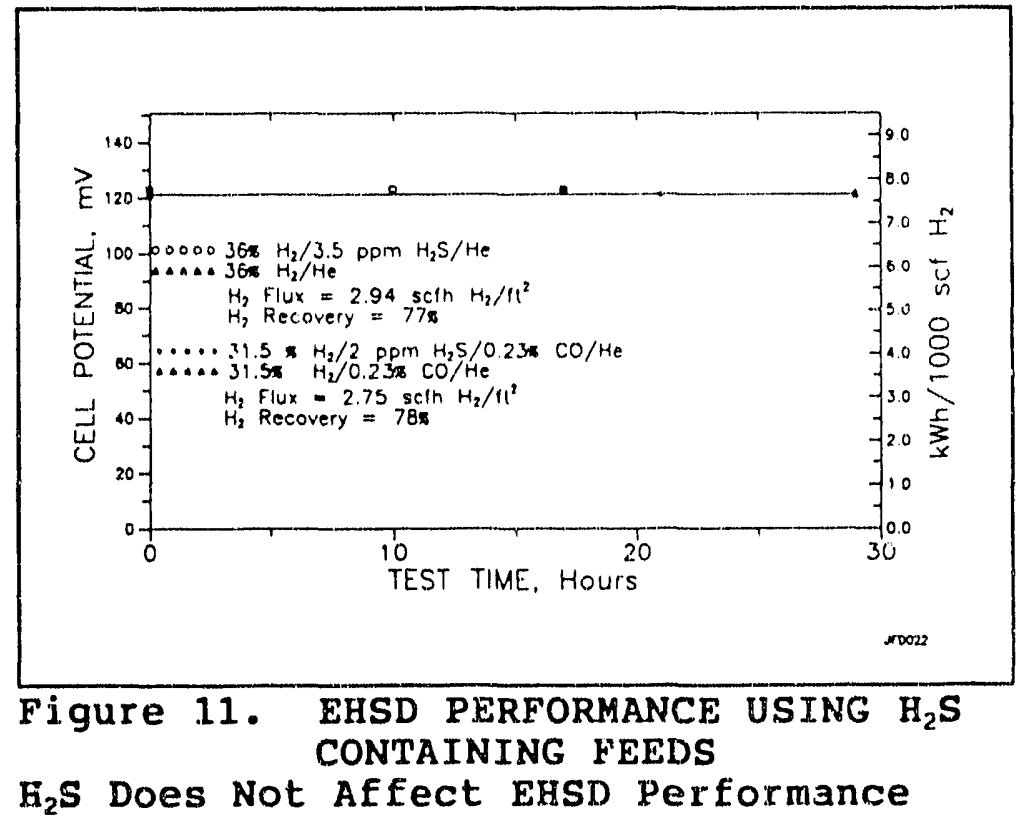




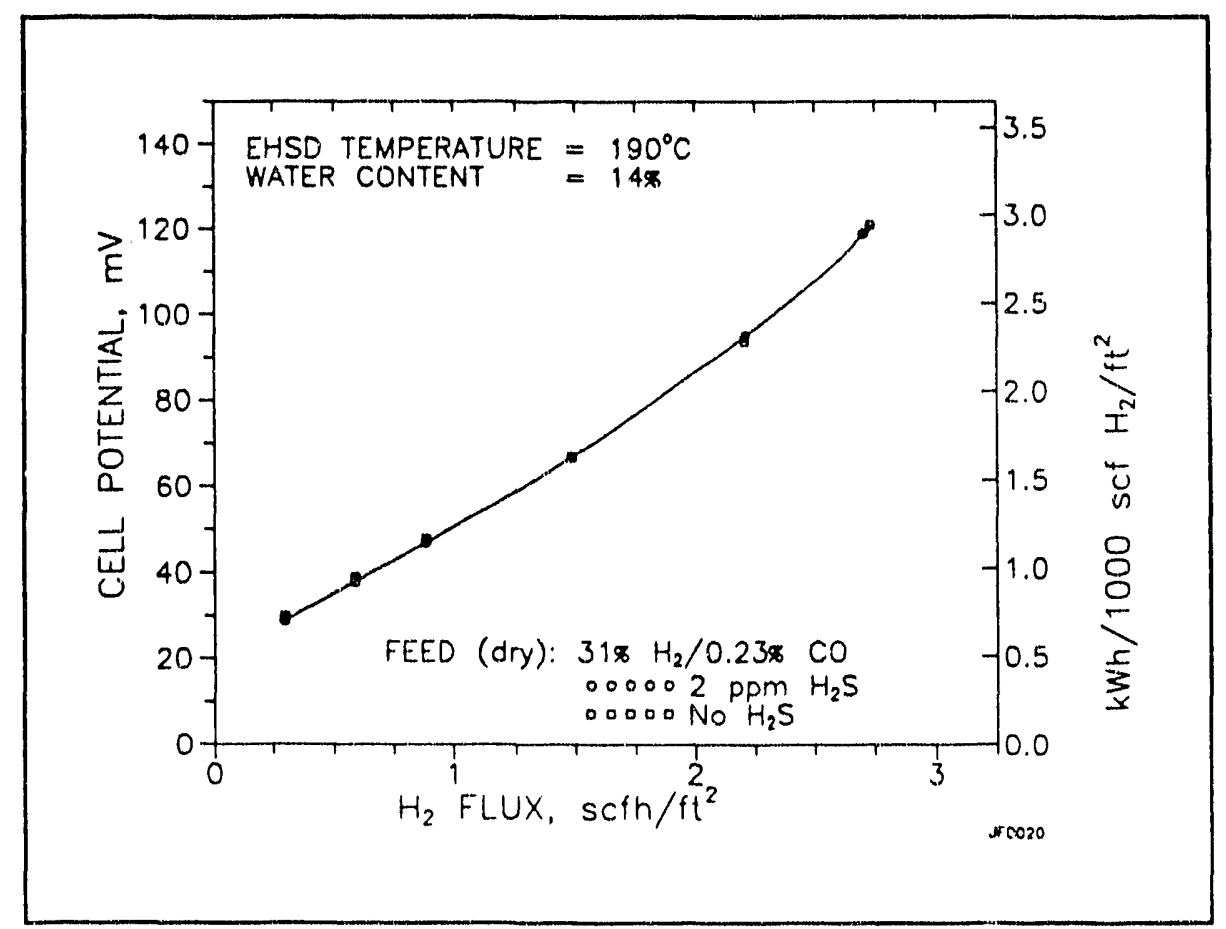

Figure 12. EHSD PERF'ORMANCE AT VARIOUS $\mathrm{H}_{2}$ FLUX USING $\mathrm{B}_{2} \mathrm{~S} / \mathrm{CO}$ CONTAINING FEED

The EHSD energy requirement with a feed containing $\mathrm{H}_{2} \mathrm{~S}$ and $\mathrm{CO}$ was also studied and it was verified that there was no increase in energy requirement due to the $\mathrm{H}_{2} \mathrm{~S} / \mathrm{CO}$ containing feed; the addition of the $\mathrm{H}_{2} \mathrm{~S}$ aid not increase the energy requirement. A comparison of the energy requirement at various $\mathrm{H}_{2}$ flux using a $32 \% \mathrm{H}_{2} / 0.2 \%$ $\mathrm{CO}$ and $2 \mathrm{ppm} \mathrm{H}_{2} \mathrm{~S}$ feed stream with a $\mathrm{H}_{2} \mathrm{~S}$ - free $32 \% \mathrm{H}_{2} / 0.2 \%$ CO feed is shown in Figure 12 .

The presence of $\mathrm{H}_{2} \mathrm{~S}$ in the feed stream will affect the purity of the product hydrogen stream. Equal concentrations of $\mathrm{H}_{2} \mathrm{~S}$ were detected in both the product hydrogen and the waste gas streams. This is due to the high solubility of the $\mathrm{H}_{2} \mathrm{~S}$ in the electrolyte. 
ENERGY RESEARCH CORPORATION

The effect of ammonia in EHSD feed gas on the energy requirement was also investigated. PAFC studies have shown that there is a performance loss due to the presence of ammonia. It is thought that this performance loss is due to a reaction with $\mathrm{NH}_{4}{ }^{+}$ and phosphoric acid at the oxidant electrode. At EHSD operating conditions, there is no oxidant supplied and therefore no performance loss is predicted. This was substantiated in subscale cell tests using a variety of $\mathrm{NH}_{3}$ containing feeds. Two feed gases were tested, one containing $2.6 \mathrm{ppm} \mathrm{NH} / 23 \% \mathrm{H}_{2}$ and the other a

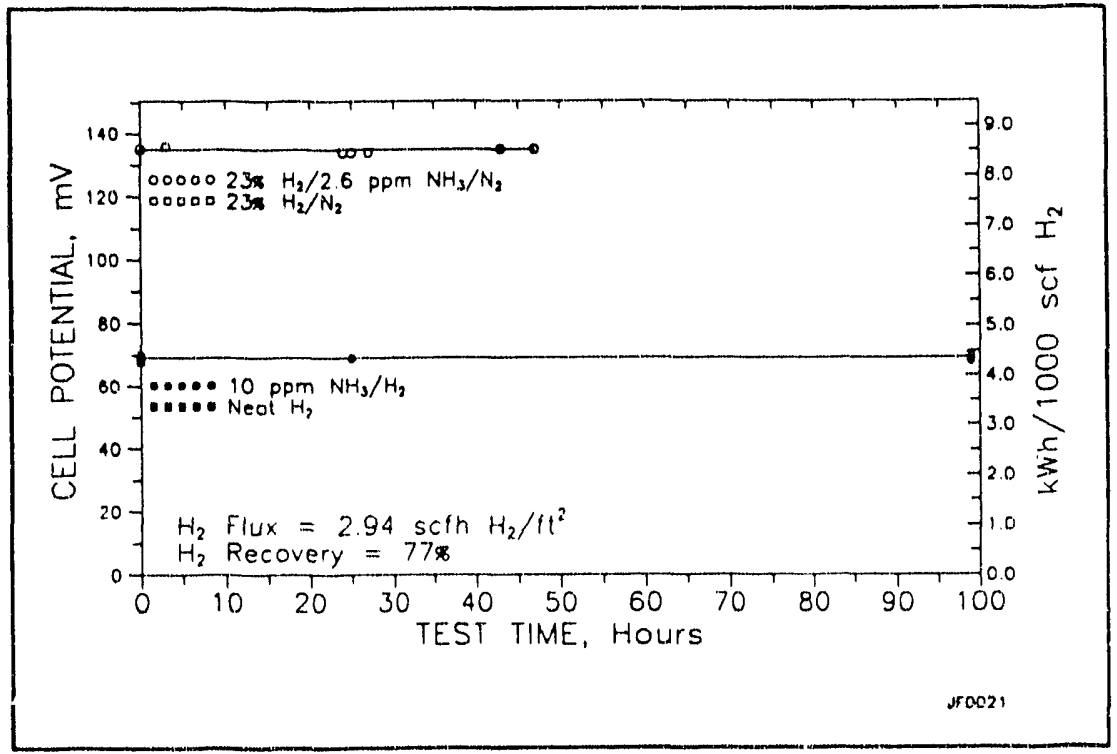

\section{Figure 13. EHSD PERFORMANCE WITE AMMONIA CONTAINING FEED}

There is No Change in Performance Due to the Presence of $\mathrm{NH}_{3}$

straight hydrogen stream with $10 \mathrm{ppm} \mathrm{NH}_{3}$. As shown in Figure 13, the EHSD performance did not change due to the addition of $\mathrm{NH}_{3}$. stable performance was observed in the short term stability tests conducted with the different $\mathrm{NH}_{3}$ concentration feed gases. 
performance. As trace quantities of these components may be present in coal gasifier product streams, a study was undertaken to determine what effect they may have on EHSD performance.

Table 2. Comparison of EHSD The sulfur tolerance of the Performance using $\mathrm{H}_{2} \mathrm{~S}$ EHSD was investigated with Containing Feed

subscale $\left(25 \mathrm{~cm}^{2}\right)$ cell tests. A variety of feed compositions containing up to $10 \mathrm{ppm} \mathrm{H}_{2} \mathrm{~S}$ were studied and the results indicate

\begin{tabular}{||l|c|c|}
\hline Feed & \multicolumn{1}{|c|}{$\begin{array}{l}10 \mathrm{ppm} \\
\mathrm{H}_{2} \mathrm{~S} \\
\mathrm{BaI}\end{array}$} & $\begin{array}{c}\text { Neat } \\
\mathrm{H}_{2}\end{array}$ \\
\hline $\begin{array}{l}\text { Energy } \\
\text { Required,mV }\end{array}$ & 66 & 67 \\
\hline
\end{tabular}
that EHSD performance is not affected by low levels of $\mathrm{H}_{2} \mathrm{~S}$. The EHSD energy requirement using neat hydrogen and a $10 \mathrm{ppm} \mathrm{H}_{2} \mathrm{~S} /$ hydrogen feed are compared in Table 2. There is no change in EHSD performance due to the addition of the $\mathrm{H}_{2} \mathrm{~S}$. Short term stability tests show that the energy requirement of a dilute $\mathrm{H}_{2}$ stream containing 3.5 ppm $\mathrm{H}_{2} \mathrm{~S}$ is comparative to the EHSD energy requirement when using a djlute $\mathrm{H}_{2} \mathrm{~S}$-free feed streams as shown in Figure 11 .

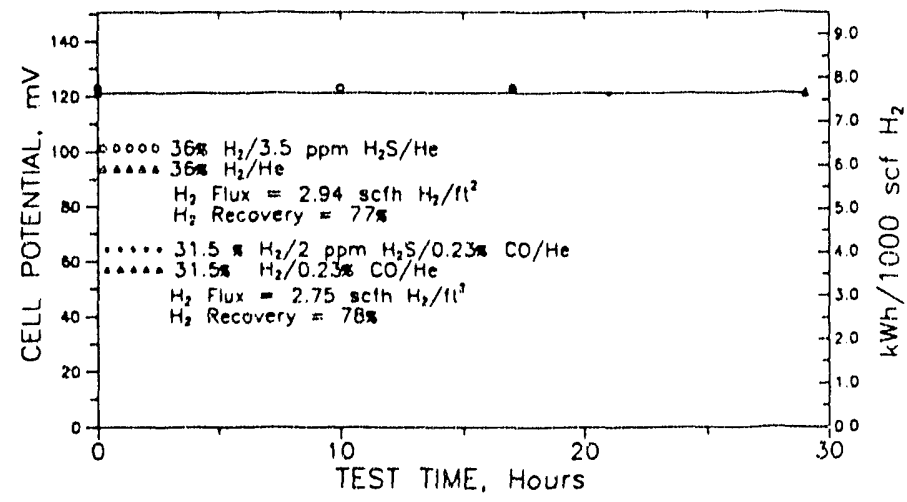

Figure 11. EHSD PERFORMANCE USING $\mathrm{H}_{2} \mathrm{~S}$ CONTAINING FEEDS

$\mathrm{H}_{2} \mathrm{~S}$ Does Not Affect EHSD Performance 
$\nabla$
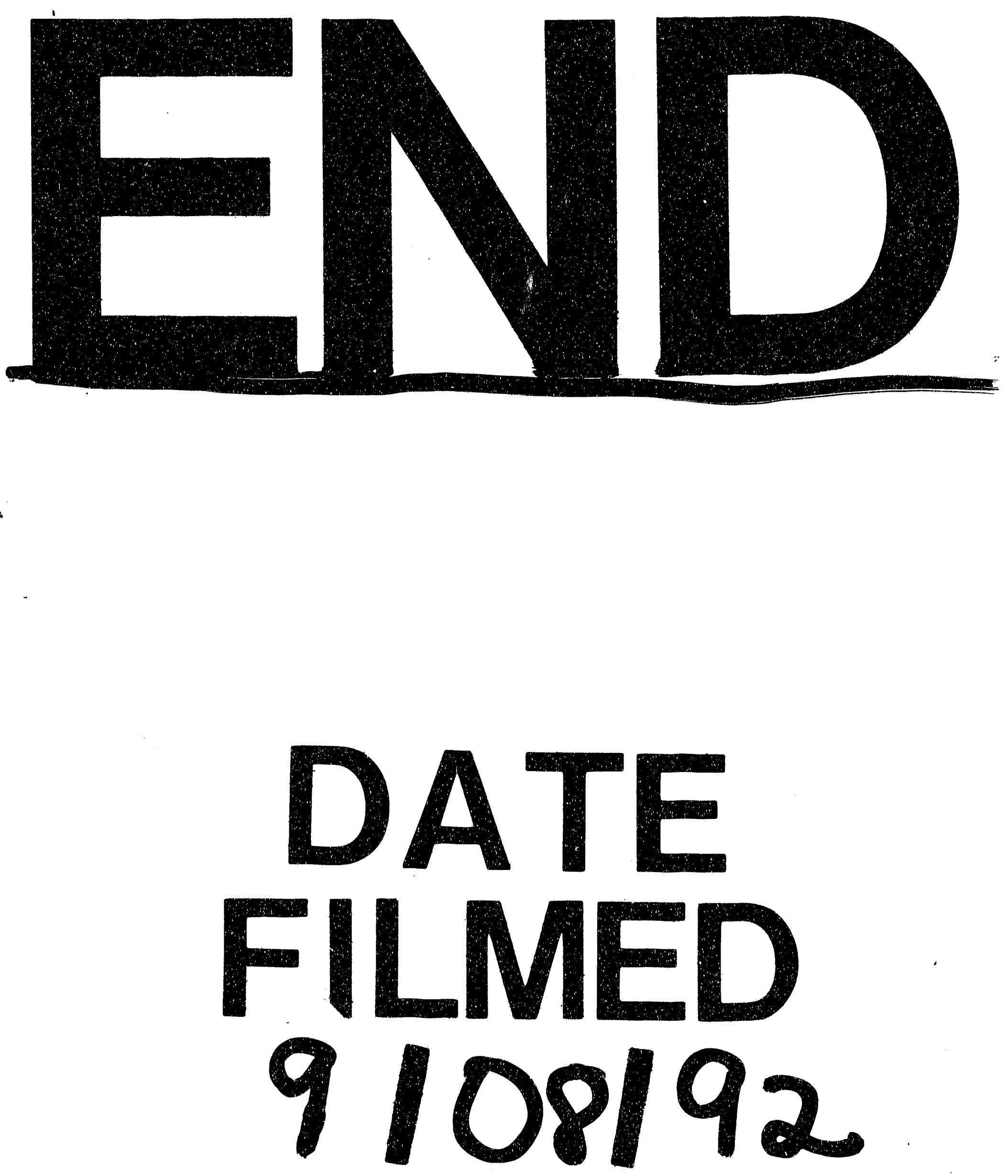


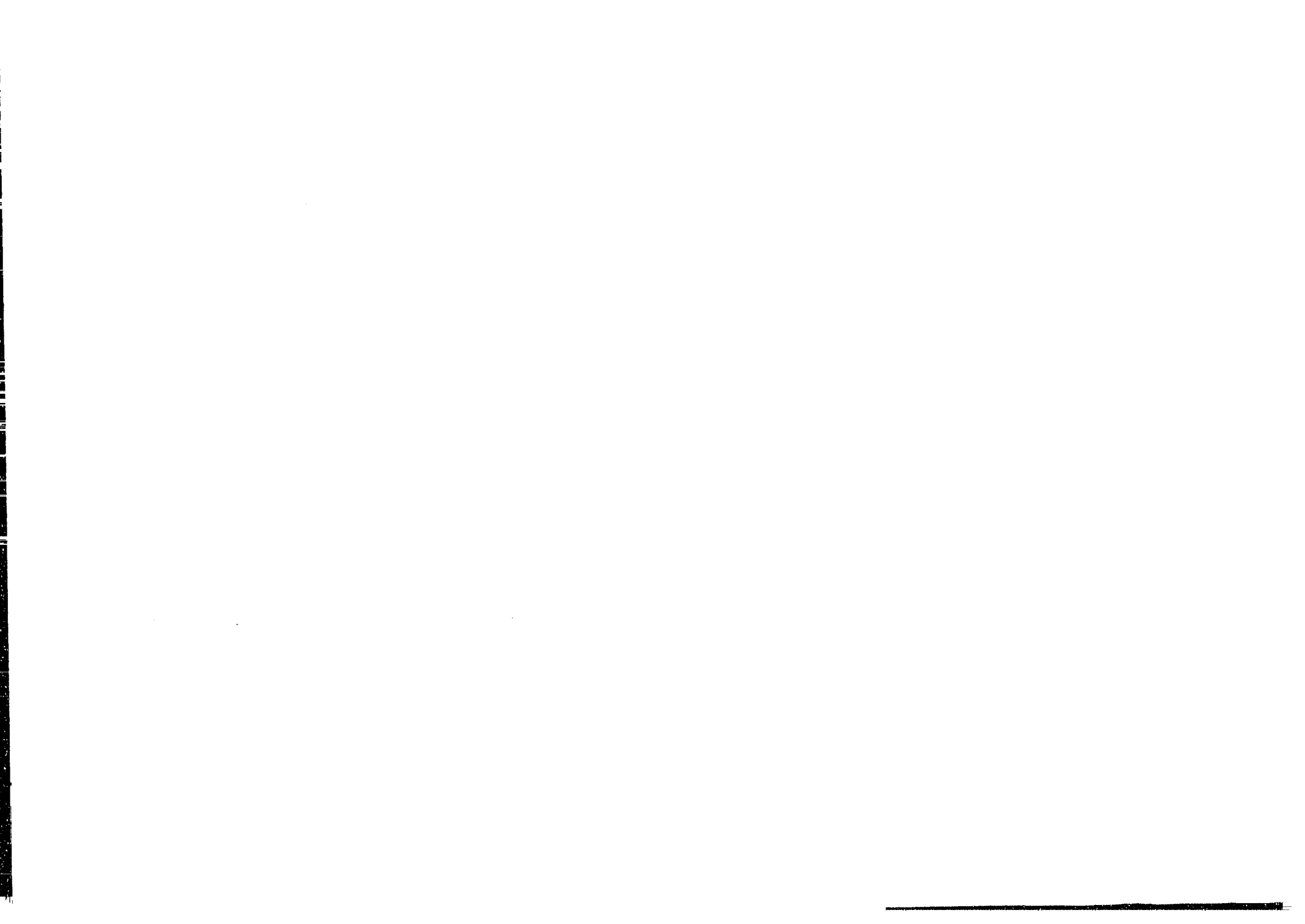

